GLOBAL JOURNAL OF MEDICAL SCIENCES VOL 10, NO. 1\&2, 2011: 13-17

COPYRIGHT@ BACHUDO SCIENCE CO. LTD PRINTED IN NIGERIA. ISSN 1596-2911

www.globaljournalseries.com; Email: info@globaljournalseries.com

\title{
REFRACTIVE ERRORS AMONG SECONDARY SCHOOL STUDENTS IN ISUIKWUATO LOCAL GOVERNMENT AREA OF ABIA STATE, NIGERIA
}

NELSON CHUKWUDI OSUCHUKWU AND EASTER CHUKWUDI OSUCHUKWU

\begin{abstract}
A study to determine the prevalence and types of refractive errors among secondary school students in Isuikwuato Local Government Area, Abia State, Nigeria was conducted. Pre-tested questionnaires were administered by two trained interviewers. Penlight examination, Hisirschberg's test, cover test, funduscopy with a direct ophthalmoscope, without and when necessary, with dilatation were performed by one optometrist. The design of this study was a cross sectional survey involving a one-time screening of 22 secondary school students in the LGA aged 11 "and 19 grouped in four yearly intervals for common refractive errors. Vision screening was conducted and those respondents found to have refractive errors were referred for further examination using the Modified Clinical Technique (MCT) criteria for referral. Furthermore, the randomness of refractive error among secondary student was tested with comparison independent sample and T-Test. When all cases of ametropia were considered, a total of $69.6 \%$ was found. Myopia predominated (36.2\%), followed by hyperopia (18.0\%) astigmatism (8.5\%) and anisometropia (6.9\%). Hence it is onus on us especially those in the medical profession to see that the menace of this refractive problem is checked.
\end{abstract}

KEYWORDS: Refractive error, Secondary School students, ametropia, Isuikwuato, Abia State, Nigeria

\section{INTRODUCTION}

In refractive errors, vision is impaired because a shortened or elongated eyeball prevents light rays from focusing sharply on the retina. (Preshel \& Prevent Blindness America 2002). Blurred vision from refractive error can be corrected with eye glasses or contact lenses. The appropriate eye glasses or contact lense is determined by refraction - determination of the refractive errors of the eye and correction by lenses. Refraction Optometry consists of placing various types of lenses in front of the patients eyes to determine which lens best improves the patient's vision (Suzanne C. S. \& Brenda B. 2004). Refractive Error (ametropia) occurs when parallel rays of light fail to converge to a sharp focus on the retina resulting in blurred vision Holden et al (2000).

Visual acuity was denoted by the smallest point on a contrasting field which can be recognized as a point distinct from the field. Wey (2004) called this the minimum distinguishable or recognizable. Refractive error can be broadly categorized on the basis of their nature. Some visual problem develop as a result of defect in image formation due to refractive error. These include short sight problem (Myopia), long sight (hyperopia), astigmatism and anisometropia. Such refractive errors can often be treated by use of artificial lenses.

Refractive error also emanate from abnormality in the visual perceptual center resulting in various kinds of transient or permanent inability to recognize objects. Ragha, (2007) in his studies on the distribution of refractive error in Nigeria reported that the most common refractive errors among secondary school students is myopia followed by hyperopia and astigmatism. Furthermore, he said that females were mostly affected in terms of the most common refractive visual problem among the secondary school students. During visual screening in 2010 ।

Nelson Chukwudi Osuchukwu, Department of Public Health, University of Calabar, Calabar. Nigeria. Easter Chukwudi Osuchukwu, School of Nursing, University of Calabar, Calabar, Nigeria. 
refractive errors. This reason prompted the study.

\section{SUBJECTS AND METHODS}

A complete list of secondary schools in Isuikwuato Local Government Area, Abia State was obtained. The population to be sampled was divided into well-defined sub groups or strata of 10 , that is 5 public secondary schools and the other 5 for private secondary schools. Both schools were zoned into $A$, $\mathrm{B}, \mathrm{C}, \mathrm{D}$ and $\mathrm{E}$. The systematic sampling method was used in a series at stages. Since the sampling fraction is 1 in 10, the students included in the sample were systematically selected through the register compiled from the schools enrolment register. Ten pieces of papers numbered 1-10 were wrapped and put in a basket and shaken. One was picked and that one happened to be 4. so from the register as the starting number is 4 , the following numbers were picked systematically $14,24,34,44$, and the students who had these numbers were included in the sample of 772 , then they were grouped by school type, age in years 11-19 years old as well as by sex male and female. Principals of selected secondary schools were approached and their permission obtained.

The design of the study was cross sectional survey involving one time screening of secondary school students aged 11-19 years in the schools used in the study as their names appeared in the school register. Questions asked during the interview included the following.

1. Are you able to see what is written on blackboard from your seat in class?

2. They were also asked if glasses have ever been prescribed for them and if they have been using them. If not using prescribed glasses, they were asked why.

Visual acuity were conducted by two ophthalmic nurses using standard Snellen's Chart at 6 meters. Subjects who were already using glasses were examined without and with their glasses. Each eye was tested separately. Subjects whose visual acuity was less than $6 / 6$ in any eye or who already used any form of refractive correction were then subjected to optometric review. This includedhistory, Hirschberg's test, cover test, penlight examination of the anterior segment and fundoscopy. Refraction was performed by the optometrist. All examinations was carried out by one optometrist. Refractive error problems were classified as hyperopia, myopia, astigmatism and anisometropia.

\section{RESULTS}

A total of 375 out of 772 secondary school students that underwent further examination were found to have different refractive errors. 97 out of 375 students including 52 males and 45 females had hyperopia. 195 out of 375 students had myopia representing 94 males and 101 females. 46 of this number had astigmatism incorporated involving 24 males and 22 females, 37 were anisometropic students made-up-of 20 males and 17 females. The remaining 397 made up of 206 males and 191 females were emmetropic representing $51.42 \%$ of 772.

It was observed that the female, were more affected than males and that of females developed these problems earlier in life than males. 
TABLE1: Classification of the Refractive Errors among Secondary School Students at Isuikwuato L.G.A. Abia State, Nigeria

MALE=M; FEMALE=F.

\begin{tabular}{|c|c|c|c|c|c|c|c|c|c|c|}
\hline \multirow[t]{2}{*}{$\begin{array}{l}\text { Age } \\
\text { Distribution }\end{array}$} & \multicolumn{2}{|c|}{$\begin{array}{l}\text { Hyperopia } \\
\text { F }\end{array}$} & \multicolumn{2}{|c|}{$\begin{array}{l}\text { Myopia } \\
\text { F }\end{array}$} & \multicolumn{2}{|c|}{$\begin{array}{l}\text { Astigmatism } \\
\text { M F F }\end{array}$} & \multicolumn{2}{|c|}{ Anisometropia } & \multicolumn{2}{|c|}{ Emmetropia } \\
\hline & $M$ & $\mathrm{~F}$ & $M$ & $\mathrm{~F}$ & $M$ & $F$ & $\mathrm{M}$ & $F$ & $M$ & $F$ \\
\hline 11-14 years & 18 & 13 & 29 & 57 & 7 & 10 & 17 & 8 & 71 & 62 \\
\hline $15-18$ years & 23 & 24 & 49 & 26 & 9 & 8 & 8 & 6 & 68 & 65 \\
\hline $19+$ & 11 & 8 & 16 & 18 & 8 & 4 & 5 & 3 & 67 & 64 \\
\hline Total & 52 & 45 & 94 & 101 & 24 & 22 & 20 & 17 & 206 & 191 \\
\hline Grand Total & 97 & $(12.6 \%)$ & 195 & $\begin{array}{l}(25 . \\
0 \%) \\
\%)\end{array}$ & 46 & $(6.0 \%)$ & 37 & $(4.8 \%)$ & 397 & $(51.42 \%)$ \\
\hline
\end{tabular}

\section{DISCUSSION}

A total of 375 students underwent further examination out of 772 referred. $195(25.0 \%)$ of these students had myopia; 97 (13.0\%) were hyperopic; 46 $(6.0 \%)$ had astigmatism $37(4.8 \%)$ were anisometropic while the remaining $397(51.42 \%)$ were emmetropic.

The above result show that the most common refractive visual problem among school children- in Isuikwuato local government area, Abia state is myopia. This finding agrees with the research carried out by Cone (2004); Kemp et al.(2005), Bonn (2006a), Brown and Kronfeld (2008) found the prevalence of myopia to be greater than other refractive error in secondary school students. Myopia (35\%); Hyperopia (19\%); Astigmatism(9\%); Anisometropia (7\%) and Emmetropia 30\%. Also Evans (2010) in his horizontal studies of secondary school refractive visual problem. Eric (2009) in his longitudinal studies on secondary school students indicated that greater percentage of the studied students tended to be more myopia and less hyperpia than to other refractive errors. This is also applicable to Bonn (2006b).

Out of 195 myopic students, 94 were males and 101 were females from the above findings, this study revealed that female students were most affected by refractive problem among secondary school students. The study also revealed that between 11 and 14 years, girls are more myopic than boys, but the number amongst boys increase after the age of 14 (Table 1). This agrees with the research carried out by Morgan (2008) Desire et al (2010); Nelson (2010) and Penda et al(2008) who indicated that girls exhibit myopia at an earlier age than boys. According to Young (2010). Penda et al. (2008) Morgan (2008) and Fry (2010) stated that the percentage of incidence of myopia increases at puberty, although no great spurt of physical growth may be exhibited.

Besides myopia, the next visual problem discovered from the research was hyperopia followed by astigmatism and anisometropia. From the interview conducted among the parents and teachers as regards their role in the early detection and management of visual problem, they gave negative response indicating that such assignment is not within the scope of their training. They said that such assignment is meant for Optometrists, Ophthalmologists, Ophthalmic nurses and Opticians. On the specific information got from the interviews of the teachers as regards the general performance of those students with obvious visual problems, they reported that these children exhibit poor classroom performance as well as loose interest in their studies. On a specific question thrown to their parents, whether they have ever wore spectacles, if yes as what age, most of them 
indicated that they started wearing glasses between ages of 40 and above indicating that this was during the presbyopic age.

While these problems are amenable totreatment and refractive correction, students with these visual problems do not present themselves for care. The positive effect of moving a student with refractive error problem from the back seat to a front seat should not be underestimated. Nearly $80 \%$ of the student with error of refraction could benefit from such cost free school health programme as occasional visual screening among secondary school students in order to detect those of them that have refractive error.

\section{CONCLUSION}

Having reviewed the finding of this study, the researchers have made these major conclusions; that the most prevalent refractive visual problem among secondary school students in Isuikwuato Local Government area of Abia State is myopia.

Secondly, the study revealed that female students are more affected by the most prevalent refractive visual problems among secondary school students. This study further reveals that between the ages of 10 and 14 years girls are more myopic than boys but the number of boys increases after the age of 14 .

The study reveals that there are more ametropia among private secondary school students than in public secondary school students.

Preventable blindness is one of our most tragic and wasteful global problem. Optometry is an essential part of the team that will eliminate this tragedy, by understanding global eye care needs and delivering effective and sustainable vision care to people in need thereby ensuring their fundamental right to sight.

\section{RECOMMENDATION}

In order to avoid visual problems or discomfort there are two possibilities;

1. Visual performance level can be increased by proper eye care services.

2. The individual can restrict his visual environment and thereby decrease environmental demand. It is this second group, which offers the greatest challenge to our profession.

Visual health education should reach parents and teach ers especially with information on eye health, eye safely, and eye problems common among students. It should be of interest-to obtain regular professional attention for students with visual problem whenever the parents/ teachers notice any abnormality in the student's eyes.

Parents and teachers was advised to report to an eye doctor (optometrist or ophthalmologist) whenever an abnormality is discovered in a child's eye especially if the child or the student is not seeing what is written on the chalkboard or if the child finds it difficult to read at near for a long time. Parents and teachers should arrange periodic vision screening on the secondary school students to identify those with visual problem so that appropriate attention can be taken.

\section{REFERENCES}

Bonn, L. M., 2006a. Clinical Refraction. Chicago. Illinois. The Professional Press Inc.

Bonn, L. M., 2006b. Clinical Refraction. Chicago Illinois. The Professional Press Inc.

Brown, E. V. L and Kronfeld, P., 2008. The Refraction cure in the United States with special reference to the first two Decades. Proc. $13^{\text {th }}$ Int. Cong. Oph. (13): 87-90.

Cone, N., 2004. Untersuchen der augen von 10060 Schulkindern nebot Vorsehl angen zur Verbesserung der Augen nachteiligen schulennirchtungen, Eine atiologische studie Leipzig.

Desire, F. A., Beattie, R. J., Newby, F. J., Swindel, J and Mark, T. C., 2010. The Pulluman Secondary School Students. Part 1. Archives of the American Academy of Optometry (31): 111-118.

Eric, G., 2009. Ein Beitrag zur Entwicklungsgeschichte der Myopie, gestutz aug die untersuchung der Augen von 4358 Schulern. Archiv. F. Ophth. Bd 17, (1) 1:79-82.

Fry, G. A., 2010. Targets and testing Procetures for the measurement of visual Acuity without Glasses. Archives of the American Academy of Optometry (30): 22-26.

Evans, I. J., 2010. Visual anomalies among children of grammer school age. Journal of American Optometric Association. (23): 663-668.

Holden, B. A., Suleman, S and Knox, K., 2000. The Challenge of 
Providing Spectacles in the developing world comm. eye hit. 13, (33): 9-10

Mann, L., 2005. Visual Analysis. $3^{\text {rd }}$ Edition Chicago. Illinois. The Professional Press Inc. 39-40.

Morgan, M. W., 2008. Synopsis of refractive status of the eye.

A symposium. Am Acad. Opt series. Vo| 5. Burgess Publi. Co. Minneapolis (35): 171-180.

Nelson, F. A and Beattie, R. J., 2010. Etiology of Refractive Error. Opt. Weekly 56, (28): 17-20.

Penda, G. S and Phave, B., 2008. Preliminary rests on study of the Refractive state with special reference to myopia Arch. Oph 45, (2): 165170.

Ragha. O. K., 2007. The Distribution of Refractive Error in Nigeria in Ophthal Phyio opt. 7, (3): 241-244.
Suzanne, C., Smeltzer and Brenda Bare., 2004 Brunner \& Suddarths Textbook of MedicalSurgical Nursing. Lippincott Williams \& Wilkins 1747-1753.

Kemp, G., Collins, S. D and Jarman, B. L, 2005. Refractive error in the eye of secondary school students as determined by retinoscopic examination with cycloplegic. Public Health Bulletin NO. 182. US. Gov. Print. Off Washington. Archives of the American Academy of Optometry, (27): 195-199.

Wey, F. W., 2004. Visual Acuity. An Analysis of the satimulus situation. Archives of the American Academy of Optometry. (32): 509-512. 